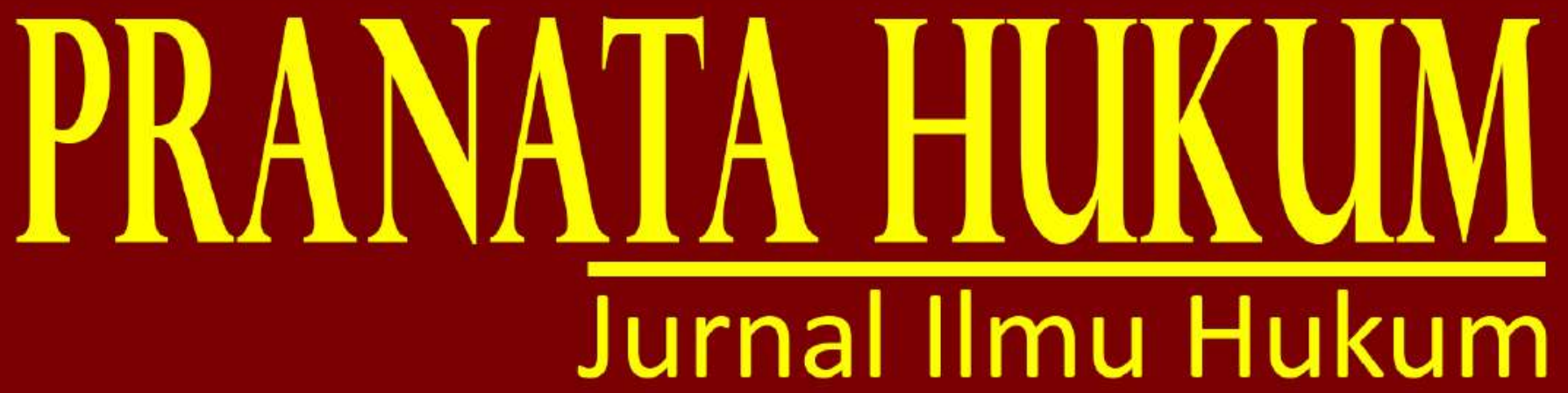

e-ISSN 2685-3213 | p-ISSN 1907-560X

SINERGITAS PEMERINTAHAN DESA DALAM PEMBENTUKAN PERATURAN DESA Anggalana

PENYELESAIAN SENGKETA PERBANKAN BERKAITAN DENGAN PERLINDUNGAN KONSUMEN Dian Herlambang, Muhammad Ridho Wijaya

ANALISIS KOMPARASI ANTARA PERLINDUNGAN PATEN BIASA DENGAN PATEN SEDERHANA BERDASARKAN UNDANG-UNDANG PATEN

Erlina, Melisa Safitri

KONSEPSI NEGARA HUKUM PANCASILA DAN IMPLEMENTASINYA DI INDONESIA Tubagus Muhammad Nasarudin

ANALISIS KEBIJAKAN PEMUNGUTAN RETRIBUSI PELAYANAN PERSAMPAHAN KEBERSIHAN DALAM RANGKA PENINGKATAN PENDAPATAN ASLI DAERAH DI KOTA BANDAR LAMPUNG Pertiwi Agustina RA, Lintje Anna Marpaung, Herlina Ratna Sumbawa Ningrum

ANALISIS KEDUDUKAN PERATURAN DESA PASCA PENGESAHAN UNDANG-UNDANG NOMOR 6 TAHUN 2014 TENTANG DESA DI DESA BADRAN SARI DAN NAMBAH REJO KABUPATEN LAMPUNG TENGAH

Baharudin, Indah Satria, Ramanda Ansori

FANATISME DAN EKSISTENSI NILAI-NILAI DEMOKRASI KADER NAHDLATUL ULAMA KOTA METRO PADA PILPRES 2019

Hendra Irawan, Ika Selviana

PERLINDUNGAN HUKUM TERHADAP PEMENANG LELANG BARANG RAMPASAN NEGARA BERUPA KENDARAAN RODA DUA YANG DIEKSEKUSI DENGAN CARA LELANG OLEH KEJAKSAAN

Okta Vianus Puspa Negara, Zainab Ompu Jainah, S. Tri Herlianto

ANALISIS PERTANGGUNGJAWABAN PELAKU TINDAK PIDANA MENGGANDAKAN SURAT PALSU UNTUK BEKERJA DI PT. GREAT GIANT PINEAPPLE HUMAS JAYA

Helmi Rangkuti, Ketut Seregig, Tami Rusli

MAGISTER HUKUM

UNIVERSITAS BANDAR LAMPUNG

\begin{tabular}{c|c|c|c|l}
$\begin{array}{c}\text { PRANATA } \\
\text { HUKUM }\end{array}$ & $\begin{array}{c}\text { Volume } \\
15\end{array}$ & $\begin{array}{c}\text { Nomor } \\
1\end{array}$ & $\begin{array}{c}\text { Halaman } \\
1-119\end{array}$ & $\begin{array}{l}\text { Bandar } \\
\text { Lampung } \\
\text { Januari } 2020\end{array}$ \\
\hline
\end{tabular}




\section{PRANATA HUKUM}

Jurnal Ilmu Hukum

Magister Hukum

Universitas Bandar Lampung

Terbit Pertama Kali, Juli 2006

Terbit Dua Kali Setahun, Setiap Januari dan Juli

EDITOR IN-CHIEF

Prof. Dr. Lintje Anna Marpaung, S.H., M.H

EDITORIAL BOARDS MEMBERS

Dr. Bambang Hartono, S.H., M.Hum

Dr. Tami Rusli, S.H., M.Hum

Dr. Erlina B, S.H., M.H

Dr. Zainab Ompu Jainah, S.H., M.H

Dr. Zulfi Diane Zaini, S.H., M.H

MANAGING EDITOR

Indah Satria, S.H., M.H

ASSISTANT EDITORS

Yulia Hesti, S.H., MH

Shany Carolina Mawuntu

\section{PENYUNTING AHLI (MITRA BESTARI)}

Prof. Dr. I Gusti Ayu Ketut Rachmi Handayani, S.H., M.M (Universitas Sebelas Maret)

Prof. Dr. I Gede A.B Wiranata, S.H., M.H (Universitas Lampung)

Dr. Nurhadiantomo, S.H., M.Hum (Universitas Muhammdiyah Surakarta)

Dr. Erina Pane, S.H., M.H (UIN Lampung)

\section{Alamat: \\ Kampus B Universitas Bandar Lampung}

Jl. Z.A Pagar Alam No.89 Labuhan Ratu, Bandar Lampung 35142

Telp: 0721-789825 Fax: 0721-770261

Email: jurnal.mh@ubl.ac.id

Jurnal PRANATA HUKUM dimaksudkan sebagai media komunikasi ,edukasi dan informasi ilmiah bidang ilmu hukum. Sajian dan kemasan diupayakan komunikatif melalui bahasa ilmiah.

Redaksi mengundang semua elemen masyarakat ,baik civitas akademika, praktisi , lembaga masyarakat, maupun perorangan yang berminat terhadap bidang hukum untuk berpartisipasi mengembangkan gagasan, wawasan, dan pengetahuan melalui tulisan untuk dimuat dalam jurnal ini. Melalui PRANATA HUKUM diharapkan terjadi proses pengembangan bidang hukum sebagai bagian penting dari rangkaian panjang proses memajukan masyarakat bangsa 


\title{
KONSEPSI NEGARA HUKUM PANCASILA DAN IMPLEMENTASINYA DI INDONESIA
}

\author{
Tubagus Muhammad Nasarudin 1
}

\begin{abstract}
The rule of law in the perspective of Pancasila which can be termed the law state of Indonesia or the rule of law state of Pancasila besides having the same elements as the rule of law in the rechtstaat and rule of law, also has specific elements that make the Indonesian law state different from the concept of the state generally known law. The difference locates in the values contained in the Preamble to the 1945 Constitution which contain Pancasila with the principles of the Belief in the one and only God and the absence of separation between the state and religion, the principle of deliberation in the implementation of state government power, the principle of social justice, kinship and mutual cooperation, as well as laws that serve the integrity of the unitary state of Indonesia. The Pancasila Law State concept is characterized by: (1) Close relations between religion and state (2) Stand on the one and only God (3) Freedom of religion in a positive sense (4) Atheism is not justified and communism is forbidden and (5) The principle of kinship and harmony. As for the main elements of the Republic of Indonesia Law State are: (1) Pancasila (2) MPR (3) Constitutional system (4) equality and (5) Free trial.
\end{abstract}

\section{Keywords: Rule of Law; Pancasila; Indonesia.}

\section{PENDAHULUAN}

Manusia dalam pergaulan hidupnya cenderung untuk selalu hidup bersama dengan manusia lainnya, Aristoteles menyebutnya sebagai "Zoon Politicon"2 dan setiap manusia menentukan dirinya sendiri dalam suatu masyarakat, dapat membentuk negara atau tidak. Berdasarkan kenyataan bahwa tiap-tiap masyarakat yang tidak merupakan negara selalu merupakan bagian dari negara. ${ }^{3}$ Istilah negara (state) pada zaman Yunani Purba masih bersifat Polis-polis atau The Greek State, yaitu pada masa pertamanya merupakan suatu tempat di puncak suatu bukit, lama kelamaan orang-orang banyak yang tinggal di tempat itu

${ }^{1}$ Dosen Fakultas Hukum Universitas Malahayati Lampung, tbnasarudin@gmail.com

2 C.S.T. Kansil, Pengantar Ilmu Hukum dan Tata Hukum Indonesia, Balai Pustaka, Jakarta, 1989, hlm. 29.

${ }^{3}$ La Ode Husen, Hubungan Fungsi Pengawasan DPR dengan BPK Dalam Sistem Ketatanegaraan Indonesia, CV. Utomo, Bandung, 2005, hlm. 20. 
mendirikan tempat tinggal bersama dan kemudian tempat tersebut dikelilinginya dengan suatu benteng tembok untuk menjaga serangan musuh dari luar. ${ }^{4}$

Dalam pandangan Socrates (470-399 SM) " negara bukanlah suatu organisasi yang dibuat untuk manusia demi kepentingan pribadinya, melainkan negara itu sebagai suatu tata susunan yang objektif, termuat keadilan bagi umum, dan tidak hanya melayani kebutuhan pada penguasa negara yang berganti-ganti orangnya. ${ }^{5}$ Pemikiran tentang negara hukum telah lama muncul jauh sebelum terjadinya Revolusi 1688 di Inggris, tetapi baru muncul kembali pada Abad XVII dan mulai populer pada Abad XIX. ${ }^{6}$ Latar belakang timbulnya pemikiran negara hukum itu merupakan reaksi terhadap kesewenang-wenangan di masa lampau. ${ }^{7}$ Oleh karena itu unsur-unsur negara hukum mempunyai hubungan yang erat dengan sejarah dan perkembangan masyarakat dari suatu bangsa. ${ }^{8}$

Sejarah timbulnya pemikiran atau cita negara hukum itu sendiri sebenarnya sudah sangat tua, jauh lebih tua dari usia Ilmu Negara atau pun Ilmu Kenegaraan. Cita negara hukum itu untuk pertama kalinya dikemukakan oleh Plato dan kemudian pemikiran tersebut dipertegas oleh Aristoteles. ${ }^{9}$ Dalam bukunya Nomoi, Plato mulai memberikan perhatian dan arti yang lebih tinggi pada hukum. Menurutnya, penyelenggaraan pemerintahan yang baik ialah yang diatur oleh hukum. Cita Plato tersebut kemudian dilanjutkan oleh muridnya yang bernama Aristoteles. Menurut Aristoteles, suatu negara yang baik ialah negara yang diperintah dengan konstitusi dan berkedaulatan hukum. ${ }^{10}$ Bagi Aristoteles, yang memerintah dalam negara bukanlah manusia melainkan pikiran yang adil, dan kesusilaanlah yang menentukan baik buruknya suatu hukum. Manusia perlu dididik menjadi warga yang baik, yang bersusila yang akhirnya akan menjelmakan manusia yang bersikap adil. Apabila keadaan itu telah terwujud, maka terciptlah suatu "negara hukum", karena tujuan negara adalah kesempurnaan warganya yang berdasarkan atas keadilan. ${ }^{11}$

Konsep negara hukum modern di Eropa Kontinental dikembangkan dengan menggunakan istilah Jerman yaitu "rechtsstaat" antara lain oleh Immanuel Kant, Paul Laband, Julius Stahl, Fichte, dan lain-lain. Sedangkan dalam tradisi Anglo Amerika konsep negara hukum dikembangkan dengan sebutan "The Rule of Law" yang dipelopori oleh A.V. Dicey. Selain itu, konsep negara hukum juga terkait

${ }^{4}$ Ibid., hlm. 20.

5 Ibid., hlm. 21. hlm. 1.

${ }^{6}$ Ni'matul Huda, Negara Hukum, Demokrasi \& Judicial Review, UII Press, Yogyakarta, 2005,

${ }^{7}$ Ibid., hlm. 1.

8 Ibid.,

${ }^{9}$ Ibid.,

10 Ibid.,

11 Ibid., hlm. 2. 
dengan istilah nomokrasi (nomocratie) yang berarti bahwa penentu dalam penyelenggaraan kekuasaan negara adalah hukum. ${ }^{12}$

Menurut Stahl, konsep negara hukum yang disebut dengan istilah "rechtsstaat" mencakup empat elemen penting, yaitu :13

1. Perlindungan hak asasi manusia

2. Pembagian kekuasaan

3. Pemerintahan berdasarkan undang-undang

4. Peradilan tata usaha negara

Sedangkan A.V. Dicey menyebutkan tiga ciri penting "The Rule of Law" yaitu:14

1. Supremasi of Law

2. Equality Before The Law

3. Due Process of Law

International Commission of Jurist menentukan pula syarat-syarat representative government under the rule of law, sebagai berikut: ${ }^{15}$

1. Adanya proteksi konstitusional

2. Adanya pengadilan yang bebas dan tidak memihak

3. Adanya pemilihan umum yang bebas

4. Adanya kebebasan untuk menyatakan pendapat dan berserikat

5. Adanya tugas oposisi

6. Adanya pendidikan civic

Prinsip-prinsip negara hukum selalu berkembang seiring dengan perkembangan masyarakat dan negara. Utrecht membedakan dua macam negara hukum, yaitu negara hukum formal atau negara hukum klasik, dan negara hukum material atau negara hukum modern. Negara hukum formal menyangkut pengertian hukum yang bersifat formal dan sempit, yaitu dalam arti peraturan perundang-undangan tertulis terutama. Tugas negara adalah melaksanakan peraturan perundang-undangn tersebut untuk menegakkan ketertiban. Tipe negara tradisional ini dikenal dengan istilah negara penjaga malam. Negara hukum material mencakup pengertian yang lebih luas termasuk keadilan di dalamnya. Tugas negara tidak hanya menjaga ketertiban dengan melaksanakan hukum, tetapi juga mencapai kesejahteraan rakyat sebagai bentuk keadilan (Welfarestate). ${ }^{16}$

Berdasarkan berbagai prinsip negara hukum yang telah dikemukakan tersebut dan melihat kecenderungan perkembangan negara hukum modern yang melahirkan prinsip-prinsip penting baru untuk mewujudkan negara hukum, maka

12 Jimly Asshiddiqie, Menuju Negara Hukum Yang Demokratis, PT. Bhuana Ilmu Populer, Jakarta, 2009, hlm. 395.

13 Ibid., hlm. 396. Lihat jg Jimly Asshiddiqie, Konstitusi\&Konstitusionalisme Indonesia, Cetakan Pertama, MKRI\&Pusat Studi Hukum Tata Negara FH UI, Jakarta, 2004, hlm. 122.

14 Ibid., hlm. 396.

15 Ibid., hlm. 396.

16 Ibid., hlm. 396-397. 
menurut Jimly Asshiddiqie terdapat dua belas prinsip pokok sebagai pilar-pilar utama yang menyangga berdirinya negara hukum, yaitu: ${ }^{17}$

1. Supremasi Hukum (Supremacy of Law)

2. Persamaan dalam hukum (Equality Before The Law)

3. Asas Legalitas (Due Process of Law)

4. Pembatasan kekuasaan

5. Organ-organ penunjang yang independen

6. Peradilan bebas dan tidak memihak

7. Peradilan tata usaha negara

8. Mahkamah konstitusi (Constitutional Court)

9. Perlindungan hak asasi manusia

10. Bersifat demokratis (Democratische Rechtaataat)

11. Berfungsi sebagai sarana mewujudkan tujuan bernegara (Welfare Rechtsstaat)

12. Transparansi dan kontrol sosial.

Dalam konstitusi ditegaskan bahwa negara Indonesia adalah negara hukum (rechtsstaat), bukan negara kekuasaan (machtsstaat). Di dalamnya terkandung pengertian adanya pengakuan terhadap prinsip supremasi hukum dan konstitusi. Dianutnya prinsip pemisahan dan pembatasan kekuasaan menurut sistem konstitusional yang diatur dalam Undang-Undang Dasar, adanya jaminan-jaminan hak asasi manusia dalam Undang-Undang Dasar, adanya prinsip peradilan yang bebas dan tidak memihak yang menjamin persamaan setiap warga negara dalam hukum, serta menjamin keadilan bagi setiap orang termasuk terhadap penyelenggaraan wewenang oleh pihak yang berkuasa. Dalam paham negara hukum itu, hukumlah yang memegang komando tertinggi dalam penyelenggaraan negara. Sesuai dengan prinsip the rule of law, andnot of man, yang sejalan dengan pengertian nomocratie, yaitu kekuasaan yang dijalankan oleh hukum, nomos.

Sebagai konsekuensi yuridis dari dianutnya paham negara hukum ini, maka di dalam Perubahan UUD 1945 telah ditegaskan pula perlindungan terhadap hakhak warga negara dan penduduk, diantaranya:

1. Segala warga negara bersamaan kedudukannya di dalam hukum dan pemerintahan dan wajib menjunjung hukum dan pemerintahan itu dengan tidak ada kecualinya.

2. Tiap warga negara berhak atas pekerjaan dan penghidupan yang layak bagi kemanusiaan.

3. Tiap-tiap warga negara berhak dan wajib turut serta dalam usaha pembelaan negara.

4. Tiap-tiap warga negara berhak mendapat pengajaran

17 Ibid., hlm. 397. 
5. Kemerdekaan dan berserikat dan berkumpul, mengeluarkan pikiran dengan lisan dan tulisan dan sebagainya ditetapkan dengan undangundang.

6. Negara menjamin kemerdekaan tiap penduduk untuk memeluk agamanya masing-masing dan beribadat menurut agamanya dan keprcayaannya itu.

7. Fakir miskin dan anak-anak terlantar dipelihara oleh negara.

Penjabaran dari hak-hak warga negara dan penduduk ini mempunyai hubungan yang erat dan tidak dapat dipisahkan. Menurut S.F. Marbun, kedudukan penduduk dan hak-hak warga negara tersebut, merupakan asas demokrasi yang menyatakan negara hendak mewujudkan keadilan sosial bagi seluruh rakyat. Artinya, keadilan sosial yang hendak diwujudkan bagi seluruh rakyat itu didasarkan pada kesadaran, bahwa manusia Indonesia mempunyai hak dan kewajiban yang sama untuk menciptakan keadilan sosial dalam kehidupan masyarakat. Demikian pula yang menyatakan dalam penyelenggaraan negara dan setiap warga negara wajib mengutamakan kepentingan negara diatas kepentingan golongan ataupun perorangan, demi perciptanya persatuan.

Menurut pendapat penulis, adanya penggabungan dalam konsep/tipe negara hukum yang diterapkan di Indonesia, sehingga muncullah gagasan baru,bahwa di Indonesia lebih mengedepankan nilai-nilai yang terkandung di dalam pancasila, sehingga muncullah gagasan konsep negara hukum pancasila sebagai perwujudan konsep hukum yang berkembang di Indonesia.

Dari gagasan itulah maka muncul pertanyaan, apa yang menjadi konsepsi negara hukum pancasila?dan bagaimana implementasinya di Indonesia?

\section{PEMBAHASAN}

\section{A. Konsepsi Negara Hukum Pancasila}

Rechtsstaat, The Rule of Law, dan negara hukum adalah istilah-istilah yang sudah berkembang dan sangat populer saat ini. Dalam penjelasan UUD 1945 tertera "Negara yang berdasar atas hukum (rechtsstaat)". Usaha untuk menunjukan kekhasan "keindonesiaannya" dilakukan dengan menambahakan atribut "Pancasila" didepan negara hukum sehingga menjadi "negara hukum Pancasila". Hal ini mengandung pengertian bahwa Pancasila sebagai rule of law bukan semata-mata sebagai peraturan yang diberlakukan bagi masyarakat Indonesia. ${ }^{18} \mathrm{Hal}$ yang demikian berarti menempatkan sistem dalam idealisme tertentu yang bersifat final, dinamis, dan selalu mencari tujuan-tujuan ideal berlandaskan ideologi Pancasila. ${ }^{19}$ Berangkat dari pemikiran diatas, maka dapat

18 Ellydar Chaidir, Negara Hukum, Demokrasi dan Konstalasi Ketatanegaraan Indonesia, Kreasi Total Media, Yogyakarta, 2007, hlm. 40.

${ }^{19}$ Ibid., hlm. 41. 
dikemukakan bahwa elemen-elemen atau ciri-ciri negara hukum Pancasila adalah: ${ }^{20}$

1. Keserasian hubungan antara pemerintah dan rakyat berdasar asas kerukunan.

2. Hubungan fungsional yang proporsional antara kekuasaan-kekuasaan negara.

3. Prinsip penyelesaian sengketa secara musyawarah dan peradilan merupakan saran terakhir.

4. Keseimbangan antara hak dan kewajiban.

Philipus M Hardjon menyatakan telaahnya atas elemen-elemen Negara Hukum Pancasila. Ia menyatakan bahwa elemen-elemen Negara Hukum Pancasila telah diketengahkan itu beranjak dari paham gotong royong dan kekeluargaan. ${ }^{21}$ Dari sini juga ia menjabarkan konsep negara hukum pancasila tersebut terdiri dari empat permasalahan, yakni:22

1. Apakah ada sifat gotong royong dan kekeluargaan dalam kehidupan masyarakat Indonesia dewasa ini? Hendaklah kita melihat konsep gotong royong yang diketengahkan dalam uraian yang menyangkut konsep negara hukum pancasila adalah faham gotong royong yang telah diangkat sebagai suatu konsep politik. Sebagai suatu konsep politik, gotong royong yang diangkat dari kehidupan asli masyarakat dijabarkan ke dalam asas-asas yang perlu mendapatkan perhatian serta dikembangkan lebih lanjut dalam kehidupan negara dan bernegara. Salah satu usaha yang dilakukan adalah menggali dan mengetengahkan asas kerukunan yang terkandung dalam paham gotong royong dan kekeluargaan untuk dijadikan asas yang melandasi hubungan antara pemerintah dan rakyat dalam negara RI

2. Apakah gotong royong dan kekeluargaan milik khas bangsa Indonesia? Kiranya dengan penegasan dalam uraian pertama bahwa gotong royong dan diketengahkan merupakan suatu konsep politik. Permasalahan itu menjadi, yang jelas gotong royong dan kekeluargaan itu hidup dalam masyarakat asli bangsa Indonesia dan kehadirannya tidak pernah dipermasalahkan. Karena dia hidup dalam masyarakat asli bangsa Indonesia, paham gotong royong dan kekeluargaan itu diangkat sebagai konsep politik.

3. Apakah masih perlu asas kerukunan kalau kita menerima konsep negara integralistik? Hal ini dapat didekati dari dua sudut, pertama, dari pemikiran Soepomo tentang negara integralistik dan kedua dari

\footnotetext{
20 Ibid., hlm. 62.

21 Ibid., hlm. 62.

22 Ibid., hlm. 62-64.
} 
pemikiran hegel sendiri, mengingat konsep negara integralistik yang diutarakan oleh Soepomo itu berasal dari pemikiran Spinoza, Adam Muler dan Hegel. Makin menyatunya negara dengan masyarakat kiranya dirasakan juga dalam negara Republik Indonesia pada alam pembangunan dewasa ini. Keadaan yang demikian itupun merupakan salah satu faktor dibutuhkannya asas kerukunan untuk menciptakan jalinan hubungan yang serasi antara pemerintah dan rakyat.

4. Apakah negara dengan perkembangan konsep rechtsstaat yang dewasa ini disebut welvaarts of verzorgingsstaat atau sociale rechtsstaat, negara hukum pancasila pun berkembang menjadi negara kesejahteraan. Dalam pembukaan UUD 1945 jelaslah tercantum tujuan negara republik Indonesia adalah memajukan kesejahteraan umum atau dalam rumusan lainnya adalah untuk mewujudkan keadilan sosial bagi seluruh rakyat Indonesia. Dari rumusan tersebut negara hukum pancasila pun mengarah kepada usaha untuk mewujudkan kesejahteraan masyarakat. Namun demikian tujuan tersebut janganlah ditafsirkan bahwa dengan adanya tujuan untuk mewujudkan kesejahteraan masyarakat berarti negara hukum pancasila merupakan negara kesejahteraan dalam pengertian welfarestaat.

\section{B. Implementasi Konsepsi Negara Hukum Pancasila Di Indonesia}

Negara hukum Indonesia yang dapat juga diistilahkan sebagai negara hukum Pancasila, memiliki latar belakang kelahiran yang berbeda dengan konsep negara hukum yang dikenal di Barat walaupun negara hukum sebagai genus begrip yang tertuang dalam Penjelasan UUD 1945 terinspirasi oleh konsep negara hukum yang dikenal di Barat. ${ }^{23}$ Jika membaca dan memahami apa yang dibayangkan oleh Soepomo ketika menulis Penjelasan UUD 1945 jelas merujuk pada konsep rechtstaat. Karena negara hukum dipahami sebagai konsep Barat, menurut Satjipto Raharjo sampai pada kesimpulan bahwa negara hukum adalah konsep moderen yang tidak tumbuh dari dalam masyarakat Indonesia sendiri, tetapi "barang impor". Negara hukum adalah bangunan yang "dipaksakan dari luar". Lebih lanjut menurut Satjipto, proses menjadi negara hukum bukan menjadi bagian dari sejarah sosial politik bangsa kita di masa lalu seperti terjadi di Eropa. ${ }^{24}$

Akan tetapi apa yang dikehendaki oleh keseluruhan jiwa yang tertuang dalam Pembukaan dan pasal-pasal UUD 1945, demikian juga rumusan terakhir negara hukum dalam UUD 1945 setelah perubahan adalah suatu yang berbeda dengan konsep negara hukum Barat dalam arti rechtstaat maupun rule of law. Dalam

${ }^{23}$ Hamdan Zoelva, Negara Hukum Dalam Perspektif Pancasila, makalah yang disampaikan pada Seminar Negara Hukum di UGM Yogyakarta, tanggal 31 Mei 2009, dalam rangka memperingati hari lahrnya Pancasila.

24 Ibid. 
banyak hal konsep negara hukum Indonesia lebih mendekati konsep socialist legality, sehingga ketika Indonesia lebih mendekat pada sosialisme, Wirjono Prodjodikoro berkesimpulan negara bahwa Indonesia menganut "Indonesia socialist legality". Akan tetapi istilah tersebut ditentang oleh Oemar Seno Adji yang berpandangan bahwa negara hukum Indonesia bersifat spesifik dan banyak berbeda dengan yang dimaksud socialist legality. ${ }^{25}$

Karena terinspirasi dari konsep negara hukum Barat dalam hal ini rechtstaat maka UUD 1945 menghendaki elemen-elemen rechtstaat maupun rule of law menjadi bagian dari prinsip-prinsip negara Indonesia. Bahkan secara tegas rumusan penjelasan UUD 1945 menegaskan bahwa negara Indonesia adalah negara yang berdasar atas hukum (rechtstaat) bukan negara yang berdasar atas kekuasaan belaka (machtstaat). Rumusan Penjelasan UUD mencerminkan bahwa UUD 1945 menghendaki pembatasan kekuasaan negara oleh hukum. ${ }^{26}$

Di pihak lain Padmo Wahyono melihat Negara Hukum Pancasila berdasarkan atas kekeluargaan yang tercantum dalam UUD 1945. Yang diutamakan di dalam asas kekeluargaan adalah rakyat banyak namun harkat dan martabat manusia tetap dihargai hal demikian itu direfleksikan oleh pasal 33 UUD 1945 yang menjelaskan bahwa yang terpenting itu adalah kemakmuran masyarakat, bukan kemakmuran perseorangan. Akan tetapi, perseorangan itu berupaya sejauh tidak mengenai hajat hidup orang banyak. Negara Hukum Pancasila dapat dipahami melalui penelaahan pengertian Negara dan pengertian hukum dilihat dari sudut asas kekeluargaan. Dalam hubungan ini Padmo Wahyono mengemukakan bahwa hukum adalah suatu alat atau wahana untuk menyelenggarakan kehidupan Negara atau ketertiban dan menyelenggarakan kesejahteraan sosial. Berpijak pada pendapat pakar hukum di atas disimpulkan bahwa dalam penyelesaian UUD 1945 digunakan istilah rechtsstaat, akan tetapi konsep rechtsstaat yang dianut oleh Negara Indonesia bukan konsep Negara hukum Barat Eropa kontinental dan bukan pula konsep rule of law dari Anglo Saxon melainkan konsep Negara Hukum Pancasila sendiri yang bercirikan : (1) hubungan erat antara agama dan negara (2) Bertumpu pada KeTuhanan Yang Maha Esa (3) Kebebasan beragama dalam arti positif (4) Ateisme tidak dibenarkan dan komunisme dilarang dan (5) Asas kekeluargaan dan kerukunan. Adapun yang menjadi unsur pokok Negara Hukum RI adalah : (1) Pancasila (2) MPR (3) Sistem konstitusi (4) persamaan dan (5) Peradilan bebas. ${ }^{27}$

\section{PENUTUP}

Negara hukum dalam perspektif Pancasila yang dapat diistilahkan sebagai negara hukum Indonesia atau negara hukum Pancasila disamping memiliki

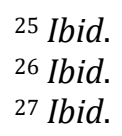


elemen-elemen yang sama dengan elemen negara hukum dalam rechtstaat maupun rule of law, juga memiliki elemen-elemen yang spesifik yang menjadikan negara hukum Indonesia berbeda dengan konsep negara hukum yang dikenal secara umum. Perbedaan itu terletak pada nilai-nilai yang terkandung dalam Pembukaan UUD 1945 yang didalamnya mengandung Pancasila dengan prinsipprinsip Ketuhanan Yang Maha Esa serta tidak adanya pemisahan antara negara dan agama, prinsip musyawarah dalam pelaksanaan kekuasaan pemerintahan negara, prinsip keadilan sosial, kekeluargaan dan gotong royong serta hukum yang mengabdi pada keutuhan negara kesatuan Indonesia.

Di sisi lain, Penegasan Indonesia adalah negara hukum yang selama ini diatur dalam Penjelasan UUD 1945, dalam Perubahan UUD 1945 telah diangkat ke dalam UUD 1945 Pasal 1 ayat (3) berbunyi "Negara Indonesia adalah negara hukum". Konsekuensi ketentuan-ketentuan ini adalah bahwa setiap sikap, kebijakan, dan perilaku alat negara dan penduduk harus berdasar dan sesuai dengan hukum. Bahkan, ketentuan ini untuk mencegah terjadinya kesewenang-wenangan dan arogansi kekuasaan, baik yang dilakukan oleh alat negara maupun penduduk.

Untuk menemukan acuan yang mungkin cocok dalam upaya menegakan negara hukum Indonesia, pandangan para pakar tentang spesifikasi konsepsi negara hukum Pancasila dapat dijadikan alternatif. Inti dari negara hukum Pancasila adalah penegakkan keadilan dan kebenaran, bukan semata-mata penegakan hukum dalam arti formal. Dalam kaitan ini, Padmo Wahyono menyatakan, bahwa konsep negara hukum Indonesia yang menyebut rechtsstaat diantara kurung memberi arti bahwa negara hukum Indonesia mengambil pola secara tidak menyimpang dari pengertian negara hukum pada umumnya (genusbegrip) yang kemudian disesuaikan dengan keadaan spesifik Indonesia. 


\section{DAFTAR PUSTAKA}

C.S.T. Kansil, Pengantar Ilmu Hukum dan Tata Hukum Indonesia, Balai Pustaka, Jakarta, 1989.

Ellydar Chaidir, Negara Hukum, Demokrasi dan Konstalasi Ketatanegaraan Indonesia, Kreasi Total Media, Yogyakarta, 2007.

Hamdan Zoelva, Negara Hukum Dalam Perspektif Pancasila, makalah yang disampaikan pada Seminar Negara Hukum di UGM Yogyakarta, tanggal 31 Mei 2009, dalam rangka memperingati hari lahrnya Pancasila.

Jimly Asshiddiqie, Konstitusi\&Konstitusionalisme Indonesia, Cetakan Pertama, MKRI\&Pusat Studi Hukum Tata Negara FH UI, Jakarta, 2004.

Jimly Asshiddiqie, Menuju Negara Hukum Yang Demokratis, PT. Bhuana Ilmu Populer, Jakarta, 2009.

La Ode Husen, Hubungan Fungsi Pengawasan DPR dengan BPK Dalam Sistem Ketatanegaraan Indonesia, CV. Utomo, Bandung, 2005.

Ni'matul Huda, Negara Hukum, Demokrasi \& Judicial Review, UII Press, Yogyakarta, 2005. 


\section{PEDOMAN PENULISAN \\ JURNAL PRANATA HUKUM}

1. Naskah bersifat orisinil, baik berupa hasil riset atau tinjauan atas suatu permasalahan hukum yang berkembang di masyarakat (artikel lepas), dimungkinkan juga tulisan lain yang dipandang memberikan kontribusi bagi pengembangan ilmu hukum.

2. Penulisan terdiri atas beberapa bab penulisan hasil penelitian terdiri dari $3 \mathrm{BAB}$, yaitu ;

BAB I. PENDAHULUAN (Latar Belakang dan Rumusan Masalah) BAB II. PEMBAHASAN (Kerangka Teori dan Analisis), dan BAB III. PENUTUP (Kesimpulan dan Saran).

3. Tulisan menggunakan bahasa indonesia maupun bahasa inggris yang memenuhi kaidah bahasa yang baik dan benar,tulisan menggunakan bahasa indonesia disertai abstrak dalam bahasa inggris (200 kata) dan Kata kunci, ketentuan ini berlaku sebaliknya.

4. Setiap kutipan harus menyebutkan sumbernya dengan format footnote. Sumber kutipan harus memuat nama pengarang, tahun penerbitan, judul buku, nama penerbit, kota penerbit, dan halaman. Contoh : Bagir Manan. 1994. Hubungan Antara Pemerintah Pusat dan Daerah Menurut UUD 1945. Pustaka Sinar Harapan. Jakarta. 1994, hlm. 19. Untuk artikel dari internet dengan susunan: nama penulis, judul tulisan digaris bawah, alamat website, waktu download/unduh.

5. Naskah harus disertai dengan daftar pustaka atau referensi ,terutama yang digunakan sebagai bahan acuan langsung. Daftar pustaka dan referensi bersifat alfabetis dengan format; nama pengarang, judul buku, nama penerbit, kota terbit, dan tahun penerbitan. Contoh: Bagir Manan. 1994. Hubungan Antara Pemerintah Pusat dan Daerah Menurut UUD 1945. Pustaka Sinar Harapan. Jakarta.

6. Panjang tulisan antara 15-25 halaman, font cambria dengan 1,15 spasi. Dalam hal hal tertentu berlaku pengecualian panjang tulisan.

7. Naskah disertai nama lengkap penulis, alamat e-mail dan lembaga tempat berafiliasi saat ini, dan hal lain yang dianggap penting. 
Jurnal PRANATA HUKUM dimaksudkan sebagai media komunikasi, edukasi, dan informasi ilmiah bidang ilmu hukum khususnya, dan ilmu sosial pada umumnya. Sajian dan kemasan diupayakan komunikatif melalui bahasa ilmiah.

Redaksi mengundang semua elemen masyarakat baik civitas akademika, praktisi, lembaga masyarakat, maupun perorangan yang berminat terhadap bidang hukum untuk berpartisipasi mengembangkan gagasan, wawasan, dan pengetahuan melalui tulisan untuk dimuat dalam jurnal ini.

Melalui PRANATA HUKUM diharapkan terjadi proses pembangunan dan pengembangan bidang hukum sebagai bagian penting dari rangkaian panjang proses memajukan masyarakat bangsa.
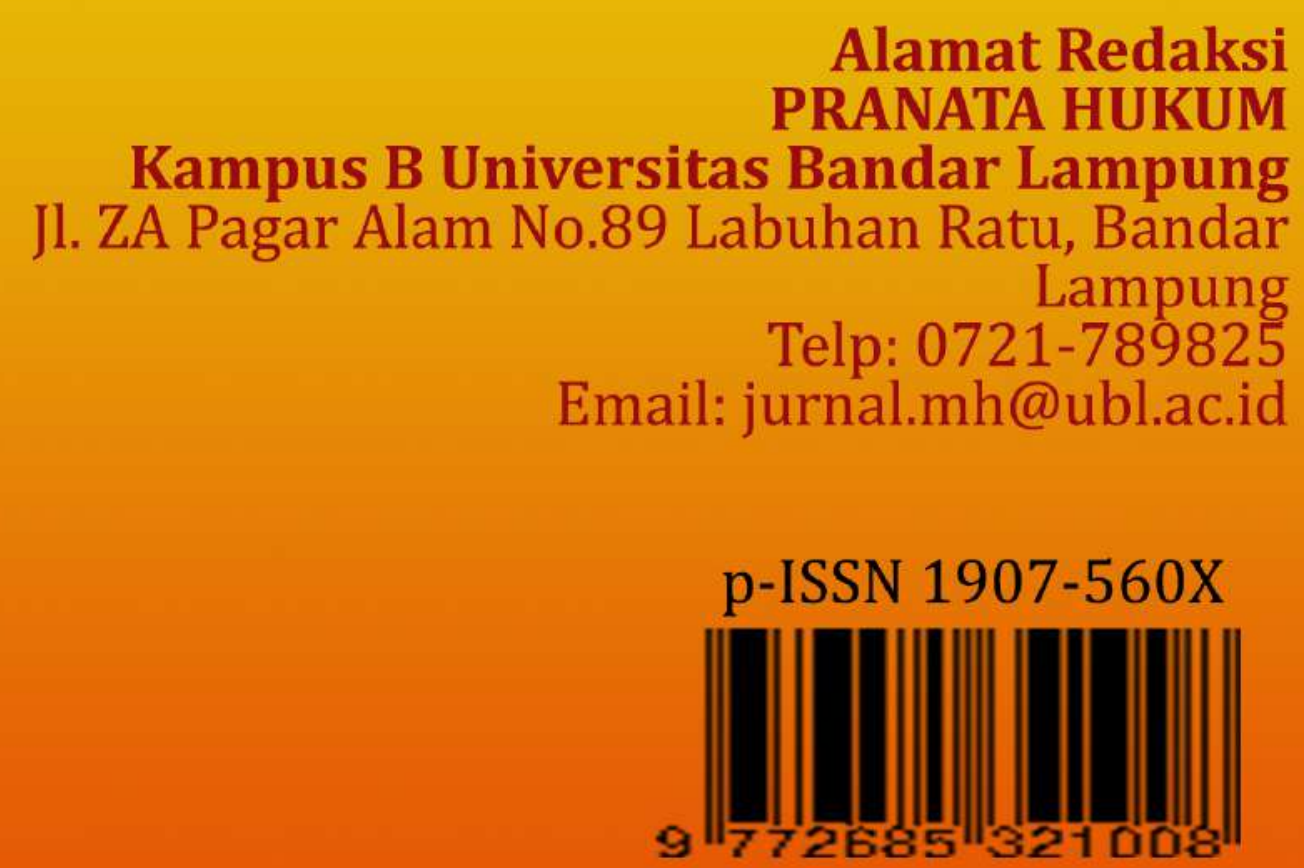